\title{
PENGARUH KARAKTERISTIK PEMERINTAH DAERAH DAN TEMUAN AUDIT BPK TERHADAP KINERJA PEMERINTAH DAERAH KABUPATEN/KOTA DI INDONESIA TAHUN ANGGARAN 2011
}

\author{
Yayuk Harumiati dan Payamta \\ Magister Akuntansi Universitas Sebelas Maret Surakarta \\ harum_cyntia@yahoo.com
}

\begin{abstract}
ABSTRAK
Penelitian ini membahas bagaimana pengaruh karakteristik pemerintah daerah dan temuan audit BPK terhadap kinerja penyelenggara pemerintah daerah kabupaten/kota di Indonesia tahun anggaran 2011. Metode pengukuran kinerja dengan menggunakan pedoman Evaluasi Kinerja Penyelenggara Pemerintah Daerah (EKPPD), dimana sumber EKPPD berasal dari Laporan Keuangan Pemerintah Daerah. Penelitian ini menggunakan populasi semua pemerintah daerah di Indonesia. Teknik pengambilan sampel dengan metode purposive sampling yaitu dengan cara memilih pemerintah kabupaten/kota yang memenuhi kriteria yang ditetapkan penulis. Sampel dalam penelitian ini adalah sebanyak 243 pemerintah daerah kabupaten/kota di Indonesia. Hasil statistik deskriptif menunjukkan bahwa secara rata-rata kinerja penyelenggara pemerintah daerah kabupaten/kota di Indonesia masuk dalam kategori tinggi. Berdasarkan hasil olah statistik SPSS dengan regresi linear dapat disimpulkan sebagai berikut bahwa tingkat kekayaan daerah (PAD), belanja modal (BM), dan temuan audit (TEMUAN) berpengaruh signifikan terhadap kinerja penyelenggara pemerintah daerah, tetapi untuk variabel belanja modal (BM) arah tersebut tidak sesuai dengan hipotesis penelitian karena hasilnya adalah negatif. Sementara itu untuk variabel ukuran daerah (ASET) tidak berpengaruh terhadap kinerja penyelenggara pemerintah daerah dengan tingkat signifikansi 5\%, dan hanya berpengaruh pada tingkat signifikansi $10 \%$. Variabel tingkat ketergantungan pada pemerintah pusat (DAU) dan status daerah (STATUS) tidak berpengaruh terhadap kinerja penyelenggara pemerintah daerah.
\end{abstract}

Kata Kunci: karakteristik pemerintah daerah, temuan audit, laporan penyelenggaraan pemerintah daerah (LPPD), evaluasi kinerja penyelenggara pemerintah daerah (EKPPD).

\section{PENDAHULUAN}

Kebijakan pemerintah Indonesia tentang otonomi daerah diawali dengan dikeluarkannya Undang-Undang No. 22 Tahun 1999 dan telah diubah dengan Undang-Undang No. 32 Tahun 2004 tentang Pemerintah Daerah. Otonomi daerah memberikan kewenangan kepada daerah untuk mengelola dan mengatur daerahnya masing-masing sesuai dengan kemampuan daerah. Salah satu bentuk evaluasi yang telah secara rutin dilakukan oleh pemerintah dalam hal ini Kementrian Dalam Negeri, adalah Evaluasi Kinerja Penyelenggara Pemerintah Daerah (EKPPD). Payung hukumnya adalah Peraturan Pemerintah Nomor 6 Tahun 2008 tentang Pedoman Evaluasi Kinerja Penyelenggaraan Pemerintah Daerah (EKPPD). Menurut PP tersebut pasal 1, EKPPD adalah suatu proses pengumpulan dan analisis data secara sistematis terhadap kinerja penyelenggaraan 
pemerintah daerah dengan menggunakan sistem pengukuran kinerja. EKPPD menggunakan LPPD sebagai sumber informasi utama yang difokuskan pada informasi capaian kinerja pada tataran pengambil kebijakan dan pelaksana kebijakan dengan menggunakan indikator kinerja kunci (Mustikarini dan Fitriasari 2012).

LPPD pemerintah daerah kab/kota perlu diawasi dan diaudit agar tidak terjadi kecurangan (fraud). Di Indonesia tugas pengawasan ini dilakukan oleh Badan Pengawas Keuangan (BPK), dimana hasil pengawasan tersebut berupa pemeriksaan keuangan, pemeringkatan kinerja dan pemeriksaan dengan tujuan tertentu. Hasil dari pemeriksaan BPK tersebut berupa opini auditor, jumlah temuan audit dan kesimpulan dalam bentuk rekomendasi terhadap pemerintah daerah.

Penelitian tentang kharakteristik pemerintah daerah dan kinerja pemerintah daerah memperoleh hasil yang berbeda-beda. Penelitian tentang kharakteristik daerah dan temuan audit BPK terhadap kinerja pemerintah daerah dilakukan oleh Mustikarini dan Fitriasari (2012), Sudarsana dan Rahardjo (2013). Suhardjianto dan Yulianingtyas (2011) mengaitkan kharakteristik pemerintah daerah dengan kepatuhan pengungkapan wajib dalam laporan keuangan pemerintah daerah. Penelitian Mustikarini dan Fitriasari (2012) menemukan bahwa ukuran daerah, tingkat kekayaan daerah, dan tingkat ketergantungan daerah terhadap pemerintah pusat berpengaruh positif terhadap skor kinerja pemda sedangkan variabel belanja daerah dan temuan audit BPK berpengaruh negatif terhadap skor kinerja pemda. Hasil penelitian Sudarsana (2013) menemukan bahwa variabel ukuran pemerintah daerah, tingkat ketergantungan daerah kepada pemerintah pusat, dan belanja modal terbukti tidak berpengaruh secara signifikan terhadap skor kinerja Pemda kabupaten/kota. Sedangkan variabel temuan audit BPK dan tingkat kekayaan daerah berpengaruh secara signifikan terhadap skor kinerja Pemda kabupaten/kota di Indonesia. Penelitian ini memberikan hasil yang berbeda dibandingkan dengan penelitian Mustikarini dan Fitriasari (2012).

\section{TINJAUAN PUSTAKA DAN HIPOTESIS \\ Teori Agency dalam Pemerintahan}

Dalam agency theory terdapat dua pihak yang melakukan kesepakatan atau kontrak, yakni pihak yang memberikan kewenangan yang disebut principal dan pihak yang menerima kewenangan yang disebut agen (Halim dan Abdullah 2006). Agency problem muncul ketika principal mendelegasikan kewenangan pengambilan keputusan kepada agen (Zimmerman 1977). Teori keagenan memandang bahwa pemerintah daerah sebagai agen bagi masyarakat principal akan bertindak dengan penuh kesadaran bagi kepentingan mereka sendiri serta memandang bahwa pemerintah daerah tidak dapat dipercaya untuk bertindak dengan sebaik-baiknya bagi kepentingan masyarakat. Agency theory beranggapan bahwa banyak terjadi information asymmetry antara pihak agen (pemerintah) yang mempunyai akses langsung terhadap informasi dengan pihak principal (masyarakat). Adanya information asymmetry inilah yang memungkinkan terjadinya penyelewengan atau korupsi oleh agen. Sebagai konsekuensinya, pemerintah daerah harus dapat meningkatkan akuntabilitas atas kinerjanya sebagai mekanisme checks and balances agar dapat mengurangi information asymmetry (Setiawan 2012) 
Perbedaan karakteristik antar daerah satu dengan daerah lainnya diasumsikan dapat mempengaruhi kinerja penyelenggara pemerintah daerah. Penelitian yang dilakukan Patrick (2007) menggunakan model Roger dalam mengemukakan karakteristik. Patrick (2007) dalam penelitianya menjelaskan karakteristik pemda dengan mengambil dua komponen, yaitu struktur organisasi dan lingkungan eksternal.

Tujuan utama dari program kerja Pemerintah daerah adalah memberikan fasilitas yang terbaik untuk masyarakat. Agar dapat memberikan pelayanan yang baik, maka harus didukung oleh pengelolaan asset yang baik pula. Oleh karena itu diperlukan adanya sumber daya dan fasilitas yang memadai untuk memberikan pelayanan kepada masyarakat. Semakin besar ukuran daerah yang ditandai dengan besarnya jumlah aset pemda, maka diharapkan akan semakin tinggi kinerja Pemda tersebut (Mustikarini dan Fitriasari 2012). Peneliti sebelumnya juga menggunakan size sebagai salah satu variabel independen. Sumarjo (2010) juga menemukan bahwa ukuran pemda berpengaruh positif terhadap kinerja keuangan. Penelitian Ramasamy et al., (2005) menjelaskan bahwa terdapat pengaruh positif ukuran (size) dengan pengukuran kinerja. Pemerintah yang memiliki ukuran besar akan dituntut untuk memiliki kinerja yang lebih baik dibandingkan pemerintah daerah yang kecil ukurannya. Dari uraian di atas, maka dapat dirumuskan hipotesis penelitian sebagai berikut:

H1: Ukuran pemerintah daerah berpengaruh positif terhadap kinerja penyelenggara Pemerintah daerah kabupaten/kota.

PAD merupakan salah satu sumber pembelanjaan daerah, jika PAD meningkat, maka dana yang dimiliki oleh pemerintah daerah akan lebih tinggi dan tingkat kemandirian daerah akan meningkat pula. Tingkat kekayaan daerah yang diukur melalui PAD terhadap total pendapatan pemda berpengaruh positif terhadap skor kinerja Pemda kabupaten/kota (Mustikarini dan Fitriasari 2012). Dari uraian di atas, maka dapat dirumuskan hipotesis penelitian sebagai berikut:

H2: Tingkat kekayaan daerah berpengaruh positif terhadap kinerja penyelenggara Pemerintah daerah kabupaten/kota.

Tingkat ketergantungan pemerintah daerah terhadap pemerintah pusat berbeda-beda yang diwujudkan dalam bentuk penerimaan Dana Alokasi Umum (DAU). PAD dan DAU merupakan sumber pendapatan daerah yang memiliki peran utama dalam pelaksanaan otonomi daerah dalam rangka mencapai tujuan utama penyelenggaraan otonomi daerah yang ingin meningkatkan pelayanan publik dan memajukan perekonomian daerah (Mardiasmo 2001). Semakin besar penerimaan dana alokasi umum (DAU) oleh suatu pemda, maka pemerintah akan lebih memantau pelaksanaan dari alokasi DAU dibanding daerah yang lebih sedikit penerimaanya, sehingga akan memotivasi pemda untuk berkinerja lebih baik karena mendapat pengawasan dari pemerintah. Semakin tinggi tingkat ketergantungan daerah kepada pemerintah pusat maka semakin tinggi skor kinerja pemda (Mustikarini dan Fitriasari 2012). Berdasarkan uraian di atas, maka hipotesis penelitian ini sebagai berikut: 
H3: Tingkat ketergantungan pada pemerintah pusat berpengaruh positif terhadap kinerja penyelenggara pemerintah daerah kabupaten/ Kota.

Belanja modal adalah pengeluaran pemerintah daerah yang manfaatnya lebih dari satu tahun anggaran dan akan menambah aset atau kekayaan daerah. Belanja modal yang besar merupakan cerminan dari banyaknya infrastruktur dan sarana yang dibangun (Sudarsana 2013). Hal ini akan mengakibatkan adanya peningkatan pelayanan dari pemerintah daerah kepada masyarakat sehingga kinerja daerah akan menjadi lebih baik. Dalam penelitian Mustikarini dan Fitriasari (2012) dengan menggunakan variabel belanja daerah, membuktikan bahwa belanja daerah berpengaruh terhadap skor kinerja pemda. Dari uraian di atas, maka hipotesis dalam penelitian ini adalah:

H4: Belanja Modal berpengaruh positif terhadap Kinerja penyelenggara Pemerintah daerah kabupaten/kota.

Penelitian tentang karakteristik daerah dengan menggunakan variabel status daerah dilakukan oleh Suhardjianto dan Yulianingtyas, dimana hasil penelitian tersebut menemukan bahwa status daerah tidak berpengaruh terhadap kepatuhan pengungkapan wajib. Sejalan dengn penelitian tersebut (Susanti 2013) meneliti pengaruh status daerah terhadap kinerja keuangan pemerintah daerah. penelitian tersebut membuktikan bahwa status daerah berpengaruh terhadap kinerja keuangan pemerintah daerah. Berdasarkan penelitian tersebut, maka hipotesis dalam penelitian ini adalah:

H 5: Status daerah berpengaruh positif terhadap kinerja penyelenggara Pemerintah daerah Kabupaten/Kota.

Temuan audit BPK merupakan kasus-kasus yang ditemukan BPK dalam laporan Keuangan Pemerintah Daerah (LKPD) atas pelanggaran yang dilakukan suatu daerah terhadap peraturan-peraturan tentang sistem pengendalian intern maupun tingkat kepatuhan terhadap ketentuan peraturan perundang-undangan yang mengakibatkan timbulnya kerugian daerah. Temuan-temuan audit tersebut dapat dilihat dari Ikhtisar hasil Pemeriksaan (IHPS) yang dikeluarkan oleh Badan Pemeriksa Keuangan (BPK). Semakin banyak pelanggaran yang dilakukan oleh pemerintah daerah, maka semakin buruk kinerja pemda tersebut. Hal ini berarti semakin besar jumlah temuan audit BPK maka semakin rendah kinerja pemerintah daerah tersebut. Mustikarini dan Fitriasari (2012) dalam penelitianya menemukan bahwa temuan audit BPK berpengaruh negatif terhadap skor kinerja pemerintah daerah kabupaten/kota. Berdasarkan uraian di atas, maka hipotesis dalam penelitian ini adalah sebagai berikut:

H 6: Temuan audit BPK berpengaruh negatif terhadap kinerja penyelenggara pemerintah daerah kabupaten/kota

\section{METODE PENELITIAN Jenis dan Sumber Data.}


Sumber data yang digunakan dalam penelitian ini adalah data dokumen yang diambil dari Laporan Keuangan Pemerintah Daerah (LKPD) dan Laporan Realisasi Anggaran (LRA) kab/kota Tahun 2011 yang diakses melalui situs www.djpt.kemenkeu.go.id. Data mengenai status daerah diperoleh dari Dirjen Otoda Kemendagri, dan data temuan audit BPK dapat diperoleh dari Laporan Hasil Pemeriksaan (LHP) yang dikeluarkan oleh Badan Pemeriksa Keuangan (BPK) untuk Tahun Anggaran 2011 yang dilaporkan dalam Ikhtisar Laporan Hasil Pemeriksaan (ILHP) semester I dan semester II Tahun 2012, yang diakses melalui situs www.bpk.go.id. Data skor kinerja penyelenggara pemda kabupaten/kota diperoleh dari hasil Evaluasi Kinerja Penyelenggara Pemerintah Daerah (EKPPD) untuk LPPD tahun anggaran 2012 yang disahkan oleh Menteri Dalam Negeri Republik Indonesia No. 120-257 Tahun 2014 tentang penetapan peringkat dan status kinerja penyelenggara pemerintah daerah secara nasional, dan diakses melalui situs www.kemendagri.go.id.

\section{Populasi dan Sampel Penelitian}

Populasi dalam penelitian ini adalah seluruh pemerintah daerah kabupaten/ kota di Indonesia, yang berjumlah 510 pemerintah daerah kabupaten/kota. Teknik pengambilan sampel dalam penelitian ini dengan menggunakan metode purposive sampling. Purposive sampling merupakan metode pengambilan sampel dengan memilih sampel berdasarkan kriteria yang sesuai dengan data yang dibutuhkan dalam penelitian (Sekaran 2011:136). Kriteria sampel yang dipilih adalah pemerintah daerah kabupaten/kota yang memiliki semua data yang lengkap meliputi Neraca, LKPD dan Laporan Hasil Pemeriksaan (LHP) dari BPK tahun anggaran 2011. Selain itu, pemerintah daerah kab/kota tersebut telah mendapatkan skor pemeringkatan kinerja penyelenggaraan pemerintah daerah dari Kementrian Dalam Negeri untuk LPPD tahun anggaran 2012. Sedangkan informasi tentang status daerah diperoleh dari situs Ditjen Otoda Kemendagri. Berdasarkan kriteria tersebut, maka jumlah pemerintah daerah kabupaten/kota yang memenuhi kriteria untuk dijadikan sampel penelitian sebanyak 243 pemerintah daerah kabupaten/kota di Indonesia.

\section{Variabel Penelitian dan Definisi Operasional \\ Variabel Independen (Independent Variable)}

\section{Ukuran Daerah}

Ukuran (size) dapat diukur dengan berbagai cara, antara lain jumlah karyawan, jumlah aktiva, total pendapatan dan tingkat produksi (Damanpour, 1991). Penelitian ini menggunakan logaritma natural (Ln) dari total aset.

2. Tingkat Kekayaan Daerah.

Kekayaan (wealth) pemerintah daerah dapat dinyatakan dengan jumlah Pendapatan Asli Daerah (Abdullah 2004). Pendapatan Asli Daerah terdiri dari pajak daerah, retribusi daerah, hasil pengelolaan kekayaan daerah yang dipisahkan, dan lain-lain pendapatan daerah yang sah. Cara mengukur variabel tingkat kekayaan daerah adalah:

$$
\text { Tingkat Kekayaan Daerah }=\underline{\text { Pendapatan Asli Daerah }}
$$

Total Pendapatan

\section{Tingkat Ketergantungan pada Pemerintah Pusat}


Dana Alokasi Umum (DAU) adalah dana yang bersumber dari pendapatan APBN yang dialokasikan dengan tujuan pemerataan kemampuan antar daerah untuk mendanai kebutuhan daerah dalam rangka pelaksanaan desentralisasi. Dalam penelitian ini variabel tingkat ketergantungan pada pemerintah pusat diukur dengan rumus:

Tingkat Ketergantungan pada Pemerintah Pusat: $\quad \underline{\text { Dana Alokasi Umum }}$

Total Pendapatan

4. Belanja Modal

Belanja modal dimaksudkan untuk mendapatkan aset tetap pemerintah daerah. yakni peralatan, bangunan, infrastruktur, dan harta tetap lainnya. Secara teoritis ada tiga cara untuk memperoleh aset tetap tersebut, yakni dengan membangun sendiri, menukarkan dengan aset lain dan membeli. Namun, untuk kasus di pemerintahan, biasanya cara yang dilakukan adalah dengan cara membeli. Proses pembelian yang dilakukan umumnya dilakukan melalui sebuah proses lelang atau tender yang cukup rumit (Abdullah, 2006).

Maka dalam penelitian ini variabel belanja modal diukur dengan rumus :

$$
\text { Belanja Modal }=\frac{\text { Belanja Modal }}{\text { Total Realisasi Belanja }}
$$

5. Status Daerah

Kontrol sosial pada masyarakat perkotaan cenderung lebih baik, sehingga pemerintah daerah selalu dituntut untuk menjalankan pemerintahan secara transparan. Pemerintah kota cenderung mematuhi standar akuntansi (Suhardjianto dan Yulianingtyas 2011). Oleh karena itu, pengukuran status daerah dengan cara memberi skor, jika status daerah adalah pemerintah kota maka diberi skor 2, dan sebaliknya jika pemerintah kabupaten maka diberi skor 1. Variabel ini pernah digunakan dalam penelitian, Addullah (2004), Suhardjianto dan Yulianingtyas (2011).

\section{Temuan Audit BPK}

Temuan audit BPK merupakan kasus-kasus yang ditemukan BPK terhadap laporan keuangan pemda atas pelanggaran yang dilakukan suatu daerah terhadap ketentuan pengendalian intern maupun terhadap ketentuan perundangundangan yang berlaku. Mustikarini dan Fitriasari (2012) menyimpulkan bahwa ada hubungan antara pengukuran kinerja pemerintah daerah dan sistem pengawasan, termasuk audit kinerja dan evaluasi program. Semakin banyak pelanggaran yang dilakukan oleh pemerintah daerah menggambarkan semakin buruknya kinerja pemerintah daerah tersebut. Variabel temuan audit BPK dalam penelitian ini diukur dengan cara:

$$
\text { Temuan Audit BPK }=\frac{\text { Temuan Audit (Dalam Rupiah }}{\text { Total Anggaran Belanja }}
$$

\section{Variabel Dependen (Dependent Variable)}


Skor kinerja pemerintah daerah kabupaten/kota berasal dari Laporan Hasil Evaluasi Pemeringkatan Kinerja Penyelenggaraan Pemerintahan Daerah berdasarkan Laporan Penyelenggaraan Pemerintah Daerah (LPPD) tahun 2012 tingkat nasional dengan range nilai antara 0 - 4. Secara rinci penggolongan kinerja penyelenggara pemerintah daerah adalah sebagai berikut: pengukuran tentang kinerja penyelenggara pemerintah daerah kabupaten/kota di Indonesia dimana jika: (1) Skor 0,00 - 0,99 masuk dalam kategori kinerja rendah, (2) Skor 1,00 1,99 masuk dalam kategori sedang, (3) Skor 2,00 - 2,99 masuk dalam kategori kinerja tinggi dan (4) Skor 3,00 - 4,00 masuk dalam kategori kinerja sangat tinggi.

\section{Variabel kontrol}

Adapun variabel kontrol dalam penelitian ini adalah sebagai berikut:

1. Besaran selisih penerimaan anggaran (SILPA).

2. Rasio Realisasi Belanja Terhadap Anggaran Belanja.

\section{Metode analisis data}

Hubungan antar variabel tersebut dapat digambarkan dengan persamaan sebagai berikut:

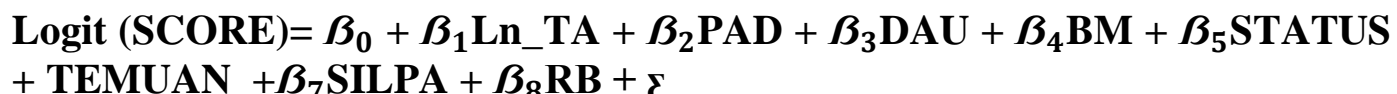

Keterangan:

$\begin{array}{ll}\text { Ln_TA } & \text { : Ukuran daerah. } \\ \text { PAD } & \text { : Tingkat kekayaan daerah. } \\ \text { DAU } & : \text { Tingkat ketergantungan dengan pusat. } \\ \text { BM } & : \text { Belanja Modal. } \\ \text { STATUS } & : \text { status pemda kab/kota. } \\ \text { TEMUAN } & : \text { Temuan Audit BPK. } \\ \text { SILPA } & : \text { Selisih Penerimaan Anggaran. } \\ \text { RB } & : \text { Realisasi Belanja. } \\ \quad \Sigma & : \text { koefisien } \text { error. }\end{array}$

\section{HASIL DAN ANALISIS DATA}

Pengujian Hipotesis

a. Uji Signifikansi Simultan (Uji F)

Berikut ini disajika uji signifikansi -F dalam penelitian yang terlihat di tabel 2 di bawah ini.

\section{Tabel 1}

Uji Statistik F

\begin{tabular}{lllllll}
\hline Model & & Sum of Squares & $\mathrm{df}$ & Mean Square & $\mathrm{F}$ & Sig. \\
\hline 1 & Regression & 33,343 & 8 & 4,168 & 14,485 &, $000^{\mathrm{a}}$ \\
& Residual & 67,329 & 234 &, 288 & & \\
& Total & 100,671 & 242 & & &
\end{tabular}

a. Predictors: (Constant), LNASET, STATUS, RB, TEMUAN, SILPA, BM, DAU, PAD

b. Dependent Variable: KINERJA 
Hasil olah statistik menunjukkan bahwa probability value dari model regresi yang digunakan dalam penelitian ini 0,000 lebih kecil dari tingkat signifikansi 5 $\%$. Hasil ini mengindikasikan model regresi yang diginakan dalam penelitian ini layak (Fit) untuk digunakan sebagai model regresi pengujian hipotesis.

b. Uji Koefisien Determinasi $\left(\mathrm{R}^{2}\right)$ ini

Hasil uji koefisien regresi dalam penelitian ini terlihat pada tabel 3 di bawah

Tabel 2

Hasil uji koefisien determinasi

\begin{tabular}{|l|l|l|l|l|l|}
\hline Model & R & R Square & $\begin{array}{l}\text { Adjusment R } \\
\text { Square }\end{array}$ & $\begin{array}{l}\text { Simatetandart } \\
\text { Error of the } \\
\text { Estimate }\end{array}$ & $\begin{array}{l}\text { Durbin } \\
\text { Watson }\end{array}$ \\
\hline 1 &, 576 &, 331 &, 308 &, 5364038 & 1,585 \\
\hline
\end{tabular}

a. Predictors: (Constant), LNASET, STATUS, RB, TEMUAN, SILPA, BM, DAU, PAD.

b. Dependent Variable: KINERJA

Dari tampilan output SPSS besarnya Adjusted $\mathrm{R}^{2}$ adalah 0,308 , hal ini berarti $30,8 \%$ variasi kinerja yang dapat dijelaskan oleh variasi 7 variabel independen LNASET, STATUS, RB, TEMUAN, SILPA, BM, DAU, PAD. Sedangkan sisanya $(100 \%-30,8 \%=69,2 \%)$ dijelaskan oleh sebab-sebab lain diluar model dalam penelitian ini.

c. Uji Koefisien Regresi

Rincian data hasil uji regersi dapat dilihat pada tabel 3 di bawah ini.

Tabel 3

Uji Signifikansi Parameter Individu

\begin{tabular}{lllllll}
\hline Model & \multicolumn{5}{c}{$\begin{array}{l}\text { Standardized } \\
\text { Cnstandardized Coefficients } \\
\end{array}$} & \multicolumn{7}{c}{$\begin{array}{l}\text { Coefficients } \\
\text { Beta }\end{array}$} & t Error & Sig. \\
\hline 1 & (Constant) &,- 816 & 1,956 & &,- 417 &, 677 \\
& PAD & 1,526 &, 722 &, 159 & 2,115 &, 036 \\
& DAU &,- 310 &, 307 &,- 066 & $-1,010$ &, 314 \\
& BM & $-2,153$ &, 466 &,- 285 & $-4,616$ &, 000 \\
& STATUS &,- 021 &, 088 &,- 014 &,- 241 &, 810 \\
& TEMUAN & $-7,137$ & 3,034 &,- 128 & $-2,352$ &, 019 \\
& SILPA & 2,255 &, 496 &, 254 & 4,547 &, 000 \\
& RB &, 051 &, 067 &, 041 &, 757 &, 450 \\
& LNASET &, 123 &, 066 &, 126 & 1,854 &, 065 \\
\hline
\end{tabular}

a. Dependent Variable: KINERJA

\section{PEMBAHASAN}

Berdasarkan pengujian uji regresi berganda maka dapat terlihat bahwa ukuran daerah (ASET) tidak berpengaruh terhadap kinerja penyelenggara pemerintah daerah dengan tingkat signifikansi 5\%. ASET hanya berpengaruh pada tingkat signifikansi $10 \%$. Hal ini mengindikasikan bahwa peran pemerintah daerah dalam meningkatkan skor kinerja pemda kabupaten/kota belum dapat berfungsi dengan baik. Pemerintah daerah yang berukuran besar dengan ditandai oleh besarnya jumlah aset daerah, seharusnya memiliki tanggung jawab yang lebih besar untuk 
memberikan pelayanan publik yang baik kepada masyarakat. Semakin baik tingkat pelayaan publik, maka akan semakin besar pula tingkat kinerja penyelanggara pemerintah daerah, dan begitu juga sebaliknya. Hal ini disebabkan, karena tingkat pelayanan publik masuk dalam indikator kinerja kunci (IKK) untuk mengukur tingkat kinerja penyelenggara pemerintah daerah. Jadi dapat disimpulkan bahwa tingginya ukuran daerah yang dilihat dari besarnya total aset daerah belum bisa menjamin tingginya kinerja penyelenggara pemerintah daerah.

Hasil penelitian ini tidak mendukung penelitian Mustikarini dan Fitriasasi (2012) yang menemukan bahwa ukuran daerah berpengaruh positif signifikan terhadap kinerja penyelenggara pemerintah daerah, dan juga tidak mendukung penelitian Sumarjo (2010), Kusumawardani (2012), Susanti dan Rita (2013) yang menemukan bahwa ukuran daerah berpengaruh positif terhadap kinerja keuangan pemerintah daerah. Penelitian ini mendukung penelitian Sudarsana (2013) yang menemukan bahwa ukuran daerah (ASET) tidak berpengaruh terhadap kinerja penyelenggara pemerintah daerah. Selain itu, penelitian ini juga mendukung penelitian Mafiana dan Lulus (2013) yang menemukan bahwa ukuran (ASET) tidak berpengaruh terhadap kinerja keuangan pemerintah daerah.

Hasil uji regresi linear berganda untuk hipotesis kedua, membuktikan bahwa tingkat kekayaan daerah (PAD) yang diukur dengan membandingkan PAD dengan total pendapatan daerah terbukti berpengaruh positif signifikan terhadap kinerja penyelenggara pemerintah daerah dengan tingkat signifikansi kurang dari 5\%. Hasil ini sesuai dengan hipotesis awal yang dinyatakan bahwa tingkat kekayaan daerah berpengaruh terhadap kinerja penyelenggara pemerintah daerah. Berdasarkan hasil penelitian ini maka terbukti bahwa pemerintah daerah kabupaten/kota yang tingkat kekayaan daerahnya besar, maka skor kinerja penyelenggaraan pemerintah juga besar, dan sebaliknya semakin kecil tingkat kekayaan daerah, maka semakin rendah pula kinerja penyelenggaraan pemerintah daerah

Hasil penelitian ini mendukung penelitian Mustikarini dan Fitriasari yang berhasil membuktikan bahwa tingkat kekayaan daerah (PAD) berpengaruh positif terhadap kinerja penyelenggara pemerintah daerah dengan tingkat signifikansi 5\%. Penelitian ini juga mendukung penelitian Sudarsana, yang menemukan bahwa tingkat kekayaan daerah berpengaruh terhadap kinerja penyelenggara pemerintah daerah kabupaten/kota. Namun, hasil penelitian ini tidak mendukung penelitian Sumarjo (2010), Mafiana dan Lulus (2013).

Hipotesis ketiga yang menyatakan bahwa tingkat ketergantungan pada pemerintah pusat (DAU) berpengaruh positif terhadap kinerja penyelenggara pemerintah daerah tidak berhasil dibuktikan. Hal ini terbukti dari hasil analisis regresi dimana tingkat signifikansinya variabel DAU yang diukur dengan membandingkan besarnya DAU terhadap total pendapatan daerah sebesar 0,314 . Jadi dapat disimpulkan bahwa besarnya DAU yang diterima oleh pemerintah daerah belum digunakan secara maksimal, sehingga besarnya tingkat ketergantungan pada pemerintah pusat (DAU) tidak dapat mempengaruhi kinerja penyelenggara pemerintah daerah. Tidak berpengaruhnya tingkat ketergantungan pada pemerintah pusat (DAU) terhadap kinerja penyelenggara daerah kemungkinan dikarenakan pemanfaatan DAU tidak efektif dan efisien, sesuai dengan indikator kinerja kunci (IKK) dalam pengukuran kinerja penyelenggaraan pemerintah daerah. 
Dilihat dari arah hasil penelitian ini, arah tersebut tidak sesuai dengan hipotesis, berarti semakin tinggi DAU maka semakin rendah kinerja penyelenggara pemerintah daerah, begitu pula sebaliknya, semakin kecil DAU maka semakin besar kinerja penyelenggara pemerintah daerah. Hasil penelitian ini tidak mendukung penelitian Mustikarini dan Fitriasari (2012), Sudarsana (2013) yang berhasil membuktikan bahwa besarnya tingkat ketergantungan pada pemerintah pusat berpengaruh positif signifikan terhadap kinerja penyelenggara pemerintah daerah.

Hasil uji regresi linear berganda untuk variabel penelitian belanja modal (BM), peneitian ini berhasil membuktikan bahwa belanja modal berpengaruh signifikan terhadap kinerja penyelenggara pemerintah daerah tetapi dengan arah yang terbalik. Hal ini berarti semakin besar belanja modal maka semakin kecil kinerja penyelenggara pemerintah daerah. perubahan arah hubungan variabel ini kemungkinan disebabkan, belanja modal yang tinggi tidak digunakan untuk peningkatan layanan kepada masyarakat sehingga kenaikan belanja modal semakin menurunkan kinerja penyelenggara pemerintah daerah. Hasil penelitian ini tidak mendukung penelitian Sudarsana (2013), yang menemukan bahwa belanja modal tidak berpengaruh terhadap kinerja penyelenggara pemerintah daerah, dan mendukung penelitian Mustikarini dan Fitriasari yang membuktikan bahwa belanja daerah berpengaruh signifikan negatif terhadap kinerja penyelenggara pemerintah daerah.

Penelitian ini tidak berhasil membuktikan, bahwa status daerah berpengaruh terhadap kinerja penyelenggara pemerintah daerah. Hal ini bisa dilihat dari hasil uji regresi dimana variabel STATUS mempunyai tingkat signifikansi sebesar 0,810 atau $81 \%$, yang berada sangat jauh di atas signifikansi $5 \%$. Jadi perbedaan status pemerintah daerah kabupaten dan kota tidak mempengaruhi kinerja penyelenggara pemerintah daerah. Sesuai dengan pedoman EKPPD, dimana penilaian kinerja penyelenggara pemerintah daerah tidak membedakan status daerah antara kabupaten dan kota. Penelitian ini mendukung penelitian Suhardjianto dan Yulianingtyas (2011), yang menemukan bahwa status daerah tidak mempengaruhi tingkat kepatuhan pengungkapan wajib. Penelitian ini tidak mendukung penelitian Susanti dan Rita (2013) yang berhasil membuktikan bahwa status daerah berpengaruh positip terhadap kinerja penyelenggara pemerintah daerah.

Hasil uji regresi limear berganda pada hipotesa keenam yang menyatakan bahwa temuan audit BPK berpengaruh negatif signifikan terhadap kinerja penyelenggara pemerintah daerah berhasil dibuktikan dalam penelitian ini, dimana variabel temuan audit BPK mempunyai tingkat signifikansi $1,9 \%$ yang jauh berada di bawah signifikansi 5\%. Jadi terbukti bahwa semakin banyak nilai temuan audit BPK, maka semakin rendah kinerja penyelenggara pemerintah daerah, dan sebaliknya semakin kecil nilai temuan audit BPK maka semakin besar kinerja penyelenggara pemerintah daerah. Penelitian ini mendukung penelitian Mustikarini dan Fitriasari (2012) serta Sudarsana dan Rahardjo (2013) yang menemukan bahwa temuan audit BPk perpengaruh negatif signifikan terhadap

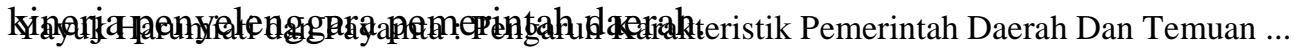

\section{KESIMPULAN, KETERBATASAN DAN SARAN Kesimpulan}


Pengujian karakteristik pemerintah daerah yang berupa tingkat kekayaan daerah (PAD), belanja modal (BM), dan temuan audit (TEMUAN) terhadap kinerja penyelenggara pemerintah daerah yang diuji dengan menggunakan regresi linear berganda menunjukan hasil bahwa tingkat kekayaan daerah (PAD), belanja modal (BM), dan temuan audit (TEMUAN) berpengaruh signifikan terhadap kinerja penyelenggara pemerintah daerah, tetapi untuk variabel belanja modal (BM) arah tersebut tidak sesuai dengan hipotesis penelitian karena hasilnya adalah negatif. Sementara itu untuk variabel ukuran daerah (ASET) hanya berpengaruh terhadap kinerja penyelenggara pemerintah daerah dengan tingkat signifikansi 10\%. Jadi dalam penelitian ini variabel ASET tidak berpengaruh terhadap kinerja penyelenggara pemerintah daerah pada tingkat signifikansi 5\%, variabel tingkat ketergantungan pada pemerintah pusat (DAU) dan status daerah (STATUS) tidak berpengaruh terhadap kinerja penyelenggara pemerintah daerah, ini berarti tidak ada perbedaan kinerja antara pemerintah daerah kabupaten dan pemerintah daerah kota. Variabel kontrol berupa selisih penerimaan anggaran (SILPA) berpengaruh positif signifikan terhadap kinerja penyelenggara pemerintah daerah, sedangkan realisasi belanja (RB) tidak berpengaruh terhadap kinerja penyelenggara pemerintah daerah. Berdasarkan pada hasil pengujian dari kedelapan variabel independen dan variabel kontrol, menunjukkan bahwa secara simultan berpengaruh terhadap kinerja penyelenggara pemerintah daerah kabupaten/kota.

\section{Keterbatasan}

Penelitian ini memiliki beberapa keterbatasan. Pertama, sampel yang digunakan dalam penelitian ini hanya bersumber dari laporan keuangan pemerintah daerah (LPPD) dan laporan hasil pemeriksaan semester I dan semester II pada tahun 2012, tetapi untuk LPPD tahun 2011. Kedua untuk skor kinerja penyelenggaraan pemerintah daerah kabupaten/kota menggunakan penilaian kinerja tahun anggaran 2012 saja, karena untuk tahun terbaru juga belum tersedia. Hal tersebut dilakukan mengingat sulitnya mencari data tentang LKPD dan LHP pemerintah kabupaten/kota untuk tahun yang terbaru. Ketiga, penelitian ini hanya menguji sebagian kecil dari variabel independen yang mempengaruhi kinerja penyelenggara pemerintah daerah kabupaten/kota yang pengaruhnya hanya sebesar $33,1 \%$, sedangkan variabel lain belum digunakan dalam penelitian ini.

\section{Saran}

Bagi penelitian selanjutnya, peneliti merekomendasikan, pertama, sampel penelitian sebaiknya menggunakan laporan keuangan pemerintah daerah (LKPD) dan laporan hasil pemeriksaan (LHP) dari badan pemeriksa keuangan (BPK) terbaru. Yang kedua, untuk penilaian kinerja penyelenggara pemerintah daerah sebaiknya menggunakan lebih dari satu tahun anggaran, mengingat penilaian kinerja bersifat kontinyu dan tidak hanya dalam satu tahun anggaran. Ketiga, sebaiknya menambahkan variabel lain yang mempengaruhi kinerja penyelenggara pemerintah daerah, yang belum dimasukkan dalam model penelitian ini seperti, lokasi daerah, jumlah SKPD, ukuran legistatif, leverage, umur administratif daerah dan variabel-variabel yang lain. Selain itu, bisa juga menggunakan indikator kinerja kunci (IKK) yang digunakan oleh pemerintah pusat sebagai dasar untuk penilaian terhadap kinerja penyelenggara pemerintah daerah. 


\section{DAFTAR PUSTAKA}

Abdullah, S. dan Halim, A. 2004. Pengaruh Dana Alokasi Umum dan pendapatan Asli Daerah Terhadap belanja Pemerintah Daerah, Studi Kasus Kabupaten/Kota di Jawa dan Bali.

Badan Pemeriksa Keuangan Republik Indonesia. Ikhtisar Hasil Pemeriksaan Semester 1 Tahun 2012. http://www,bpk.go.id diakses 10 Agustus 2014.

Badan Pemeriksa Keuangan republik Indonesia. Ikhtisar Hasil Pemeriksaan Semester 2 Tahun 2012. http://www,bpk.go.id diakses 10 Agustus 2014.

Bastian, Indra. 2005. Akuntansi sektor Publik: Suatu Pengantar. Jakarta: Erlangga. Blazek dan Macskova. 2010. Regional Impact of Non-Regional Policies, Sectoral Policies, Territorial Impact Assesment, Regional Policy, Public Investment. Cech republic. Journal Regional Studies 44 (06):1-82.

Damanpour, F. 1991. Organizational Innovation: A Meta Analysis of Effects of Determinants and Moderators. Academy of Management Journal, Vol.34:555-590.

Gadfrey, et al. 2004. Rural Taxation in Uganda: Implications for Growth, Income Distribution, Local Government Revenue and Poverty Reduction. Uganda Rural Taxation Studies: Final report 35 (010:1-46)

Ghozali, Imam. 2011. Aplikasi Analisis Tingkat Multivariate dengan Program IBM SPSS 19. Semarang: Badan Penerbit Universitas Diponegoro.

Halim, A. Abdullah. 2006. Hubungan dan Masalah keagenan di Pemerintah Daerah. jurnal Akuntansi pemerintahanVol.2 No.2

Keputusan Kementrian Dalam negeri Republik Indonesia N0. 120-251. 2014. Penetapan Peringkat dan Status Kinerja Penyelenggara Pemerintah Daerah Propinsi, Kabupaten dan Kota berdasarkan LPPD Tahun Anggaran 2012 Tingkat Nasional.

Kusumawardhani, Media. 2012. Pengaruh Size, Kemakmuran, Ukuran Legislatif, Leverage Terhadap Kinerja Keuangan Pemerintah Daerah Di Indonesia. Accounting Analysis Journal: Universitas Negeri Semarang

Lane, Jan-Erik. 2000. The Public Sector - Concepts, Models and Approaches. London: SAGE Publications.

Mardiasmo. 2006. Perwujudan Transparansi dan Akuntabilitas Publik Melalui Akuntansi Sektor Publik, Suatu Sarana Good Governance. Jurnal Akuntansi Pemerintah Vol.2 No. 1. Hal 1-17. http://www.bpk.go.id

Mardiasmo. 2009. Akuntansi Sektor Publik. Jogjakarta: Penerbit Andi.

Riduwan. 2013. Metode dan Teknik Menyusun Tesis. Bandung: Alfabeta

Mustikarini, W. A. dan Fitriasari, D. 2012. Pengaruh Kharakteristik Pemerintah Daerah Dan Temuan Audit BPK Terhadap Kinerja Pemerintah Daerah. SNA 15 Makasar.

Patric, P. A. 2007. The Determinant of Organizational Inovativeness: The Adoption of GASB 34 in Pennsylvania Local Goverment. Unpublished Ph.D Dissertation. Pennsylvania State University

Peraturan Menteri Dalam Negeri Nomor 73 tahun 2009 Tentang Tatacara Pelaksanaan Evaluasi penyelenggara Pemerintah Daerah.

Peraturan Pemerintah Nomor 24 Tahun 2005 Tentang Standar Akuntansi Pemerintahan.

Peraturan Pemerintah Nomor 6 Tahun 2008 Tentang Pedoman Evaluasi Penyelenggaraan Pemerintah Daerah. 
Setiawan, Wahyu. 2012. Pengaruh Akuntabilitas Laporan Keuangan Pemerintah Daerah (LKPD) terhadap Tingkat Korupsi Pemerintah Daerah di Indonesia. Skripsi Sarjana. Universitas Diponegoro Semarang.

Sekaran, Uma. 2006. Research Methods for Business: Metodologi penelitian untuk Bisnis. Edisi 4. Jakarta: Salemba Empat

Setyaningrum, Dyah dan Syafitri, Febriyani. 2012. Analisis Pengaruh Kharakteristik Daerah Terhadap Tingkat Pengungkapan Laporan Keuangan. Jurnal Akuntansi dan Keuangan Indonesia Vol. 9 Nomor 2.

Sheila. 2013. Pengaruh PAD, DAU, dan DAK terhadap pengelolaan Anggaran Belanja Modal. Accounting Analysis Journal (3): 89-95.

Sumarjo, Hendro. 2010. Pengaruh Kharakteristik Pemerintah Daerah terhadap Kinerja Keuangan Pemerintah Daerah, Studi Empiris pada Pemerintah Daerah Kabupaten/Kota di Indonesia. Skripsi sarjana. Universitas Sebelas Maret Surakarta.

Suhardjianto, Djoko dan Yulianingtyas, Rena Rukmita. 2011. Pengaruh Karakteristik Pemerintah Daerah Terhadap Kepatuhan Pengungkapan wajib dalam Laporan Keuangan. Jurnal Akuntansi dan Auditing. Vol 8. No. 1.

Suhardjianto, el al,.2010. Influence of Parliament Charakteristics: Evidence From Indonesian Municipalities. Jurnal Public Policy. Januari 2010.

Undang-Undang Nomor 32 Tahun 2004 Tentang Pemerintah Daerah.

Undang-Undang Nomor 17 Tahun 2003 Tentang keuangan Negara.

Undang-Undang Nomor 1 Tahun 2004 Tentang Perbendaharaan Negara.

Undang-Undang Nomor 33 Tahun 2004 Tentang perimbangan Keuangan Antara Pemerintah Pusat dan Pemerintah Daerah.

Undang-Undang Nomor 15 Tahun 2004 tentang Pemeriksaan Pengelolaan dan Tanggung jawab keuangan Negara. 